\title{
Hydrochemické vlastnosti zdrojů termálních minerálních vod v oblasti Pasohlávky - Laa an der Thaya
}

\author{
Hydrochemical properties of thermal mineral water sources in the Pasohlávky \\ - Laa an der Thaya region
}

\section{Bibiána Pasternáková1 $\square$, Tomáš Kuchovský1, Kateřina Chroustová', Adam Říčka', Magdalena Bottig ${ }^{2}$}

'Ústav geologických věd, Př́rodovědecká fakulta, Masarykova univerzita, Kotlářská 267/2, 61137 Brno, Česká republika

${ }^{2}$ Geologische Bundesanstalt / Geological Survey of Austria, Neulinggasse 38, 1030 Wien, Österreich

\section{Key words:}

Jurassic sediments, carbonate aquifer, thermal mineral water, stable isotopes, hydrochemistry, groundwater recharge, meteoric water, primary marine water, deep well

\section{凸437337@mail.muni.cz}

Editor:

Jiří Faimon

\section{Doporučená citace článku:} Pasternáková, B., Kuchovský, T., Chroustová, K., Říčka, A., Bottig, M. (2021). Hydrochemické zhodnocení zdrojů termálních minerálních vod voblasti Pasohlávky - Laa an der Thaya. - Geologické výzkumy na Moravě a ve Slezsku, 28, 1-2, 105-111.

\begin{abstract}
The South Moravian region of Pasohlávky and the Lower Austrian town of Laa an der Thaya belongs to the areas of intensive use of thermal mineral water for recreational and balneological purposes. Thermal mineral water is extracted from a deep-seated Jurassic aquifer, mainly composed of carbonates. These carbonates overlie the crystalline bedrock, which is dipping towards the southeast below the Outer Western Carpathians. Due to this trend, there are two developments of the Jurassic sediments that differ in their lithological composition and are vertically separated by the Mušov transition zone. To the northwest from this zone, there is a shallower carbonate development and in the southeast, there is a deeper development which is composed of permeable carbonates together with impermeable marls. The Neogene sediments of Carpathian foredeep are deposited on the top of the Jurassic carbonate structure. Thermal mineral water is exploited by two hydrogeological wells - Muš-3G (Pasohlávky, $1455 \mathrm{~m}$ deep) and Laa Th N1 (Laa an der Thaya, $1448 \mathrm{~m}$ deep) situated in the shallower carbonate part of the Jurassic aquifer. The aim of this study, that summarizes the important partial outputs of the cross-border project Interreg HTPO (Hydrothermal Potential of the Area, ATCZ167), is to specify and clarify the origin, genesis and the processes of water formation based on the hydrochemical evaluation of thermal mineral water. For this purpose, both the final reports of studied wells and especially results from newly performed analyses of stable isotopes of hydrogen $\delta^{2} \mathrm{H}$ and oxygen $\delta^{18} \mathrm{O}$ were used. The $\delta^{18} \mathrm{O}$ and $\delta^{2} \mathrm{H}$ values of water samples from the $M u s ̌-3 G$ well varies from $-12,77 \%$ to $-12,03 \%$ and from $-92,23 \%$ to $-88,05 \%$, respectively, while water samples from the Laa Th $\mathrm{N} 1$ well are isotopically heavier with $\delta^{18} \mathrm{O}$ values ranging from $-7,04 \%$ to $-6,31 \%$ and with $\delta^{2} H$ values ranging from $-51,04 \%$ to $-49,33 \%$. In the Pasohlávky region we suppose it is an isotopically depleted water that has infiltrated in the cold climatic period (glacial). Evaluation of the chemical composition revealed that although the thermal waters from both areas of the hydrogeological structure are of the same $\mathrm{Na}-\mathrm{Cl}$ type, their total mineralization differs significantly. Lower total mineralization in the Pasohlávky area (approx. $2,2 \mathrm{~g} / \mathrm{L}$ ) is also associated with higher relative concentrations of bicarbonate ions $\left(\mathrm{HCO}_{3}^{-}\right)$and atmogenic nitrogen, typically bound to infiltrated meteoric waters. The thermal water in this area is mostly of meteoric origin, mixed with primary marinogenic water. In the Laa an der Thaya region, there is water with higher total mineralization (approx. $11 \mathrm{~g} / \mathrm{L}$ ) and lower relative concentrations of $\mathrm{HCO}_{3}^{-}$, which together with the results of isotope analyses indicates a higher content of primary seawater. The marinogenic origin of waters also confirms the presence of bromides and iodides. The process of mixing primary marine waters with infiltrated meteoric waters significantly contributes to the chemical composition of the studied waters in both areas, while the original marinogenic water type of $\mathrm{Na}-\mathrm{Cl}$ is preserved.
\end{abstract}




\section{Úvod}

Okolí jihomoravské obce Pasohlávky a rakouského města Laa an der Thaya (dále jen Laa), ležícího těsně u hranic s Českou republikou, patří k oblastem intenzivního využívání termálních minerálních vod pro balneologické účely. Tyto termální vody jsou vázány na karbonátový kolektor jurského stáří vyskytující se v hloubkách přesahujících $1 \mathrm{~km}$. Cílem této studie je, na základě hydrochemického zhodnocení termálních minerálních vod a nově vykonaných izotopových analýz vodíku a kyslíku, upřesnit a objasnit původ, genezi a procesy formování vod.

\section{Lokalizace a přírodní poměry}

Termální minerální vody jsou vázány na hluboko položené těleso jurských sedimentů, $\mathrm{z}$ něhož jsou jímány prostřednictvím dvou hydrogeologických vrtů. Jedná se o 1455 m hluboký vrt Muš-3G (N 4854'17,8114“ E 16³4‘35,0305“), situovaný u s. okraje vodní nádrže Nové Mlýny I v blízkosti obce Pasohlávky v Jihomoravském kraji, a o 1448 m hluboký vrt Laa Th N1 (N 4843‘53,7421“ E $\left.16^{\circ} 23^{`} 22,2877^{\prime \prime}\right)$ nacházející se ve městě Laa v Dolním Rakousku (obr. 1, tab. 1). Vrt Muš-3G, vyhloubený v roce 1990, představuje první cílený vyhledávací vrt na termální vody na jižní Moravě. Na základě poznatků z vrtu Muš-3G byl v roce 1995 vyhlouben vrt Laa Th N1 s cílem zajistit obdobný zdroj termální vody (Michalíček et al. 2005). Teplota čerpaných vod z obou vrtů dosahuje $40-45^{\circ} \mathrm{C}$. V roce 1995 byl vybudován i vrt Pas-2G (N 4854'19,7256“ E $\left.16^{\circ} 32^{\prime} 27,3678^{\prime \prime}\right)$, situovaný $2,6 \mathrm{~km}$ z. od vrtu Muš-3G, který byl projektován jako vrt reinjektážní se záměrem vtlačovat vytěženou termální vodu z vrtu Muš-3G zpět do horninového prostředí. Jedná se $1200 \mathrm{~m}$ hluboký vrt

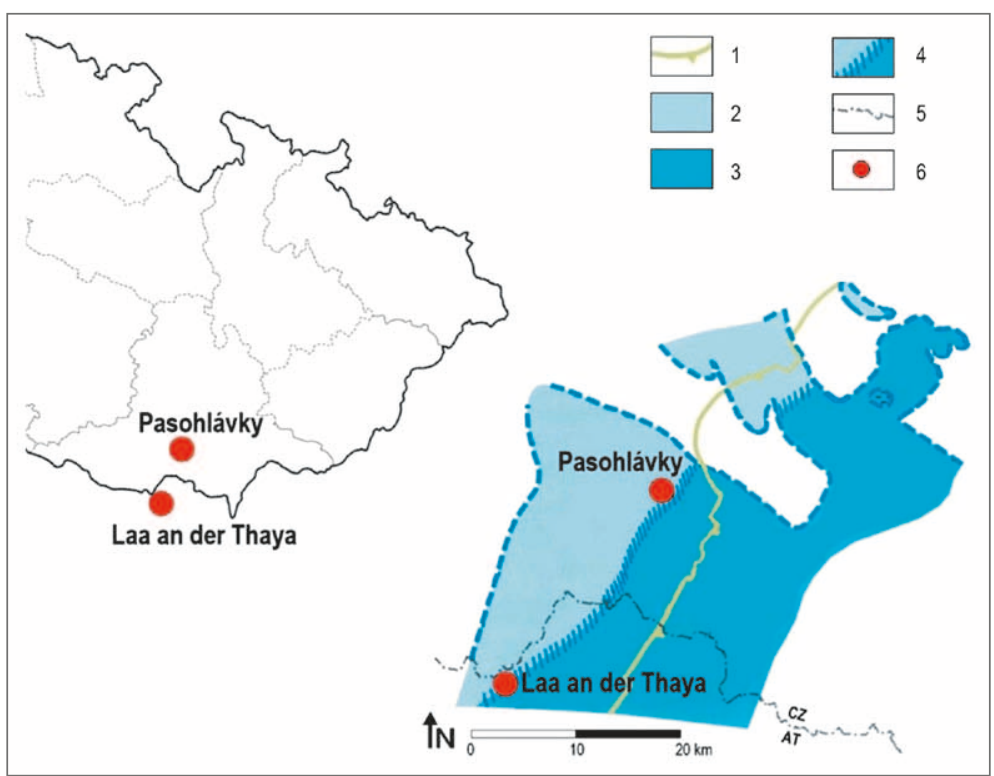

Obr. 1: Rozsah jurských sedimentů s lokalizací studovaných oblastí (Adámek 2005, upraveno). Legenda: 1 - čelo příkrovů Vnějších Západních Karpat; 2 - karbonátový vývoj jury; 3 - peliticko-karbonátový vývoj jury; 4 - mušovská přechodová zóna; 5 - státní hranice; 6 - lokalizace studovaných oblastí.

Fig. 1: Extent of Jurassic sediments with the location of the studied areas (Adámek 2005, edited). Legend: 1 - Western Carpathian thrust front; 2 - Jurassic, carbonate platform; 3 - Jurassic, basinal development; 4 - Mušov transition zone; 5 - state border; 6 - localization of studied areas. vyhloubený do hornin miocénu a propustných sedimentů jury. Perforované úseky vrtu jsou umístěny v prostředí jurských hornin (Adámek et al. 1995). Vrt Pas-2G v současnosti neslouží jako zdroj termální vody.

Z regionálně-geologického hlediska leží zájmové území v oblasti jižní části karpatské předhlubně, která je tvořena neogenními sedimenty eggenburgu-ottnangu, karpatu a spodního badenu. Na jihovýchodě se předhlubeň noří pod flyšové př́krovy Vnějších Západních Karpat. Podloží karpatské předhlubně je budováno autochtonním mezozoikem uloženým bezprostředně na krystaliniku. Autochtonní mezozoikum je zastoupeno převážně jurskými sedimenty, které jsou zdrojem termálních minerálních vod. Jurská sedimentace probíhala ve dvou cyklech - spodním a vrchním. Pro spodní cyklus (lias, dogger) jsou charakteristické klastické až peliticko-klastické sedimenty (Adámek 1986). Vrchní sedimentační cyklus (kelloway až tithon) je reprezentován na SZ karbonátovým směrem na JV peliticko-karbonátovým vývojem jury 1974). Vznik dvou vývojů byl zapř́íčiněn upadajícím razně větší mocnost. Přechod těchto vývojů je pozvolný a tvoří poměrně širokou tzv. mušovskou přechodovou zónu (Adámek 1974), která má významný vliv z hlediska formování chemismu vod (obr. 1). Peliticko-karbonátový vývoj jury, situovaný jv. od mušovské zóny, představuje první hydrogeochemickou zónu, ve které se vyskytují silně mineralizované vody ( 20 až $56 \mathrm{~g} / \mathrm{L})$ výrazného $\mathrm{Na}-\mathrm{Cl}$ až $\mathrm{Ca}-\mathrm{Cl}$ typu. Směrem na severozápad od mušovské zóny se jurské sedimenty vynořují a přecházejí do druhé hydrogeochemické zóny tvořené karbonátovým vývojem jury. Pro tuto zónu jsou charakteristické vody $\mathrm{Na}-\mathrm{Cl}$ typu, $\mathrm{Na}-\mathrm{HCO}_{3}$ až Ca- $\mathrm{HCO}_{3}$ podtypu s nižšími celkovými mineralizacemi $(0,5$ až $12 \mathrm{~g} / \mathrm{L})$ (Adámek et al. 1990). Jak zdroje termálních minerálních vod Muš-3G a Laa Th N1, tak i reinjektážní vrt Pas-2G jsou vyhloubeny $\mathrm{v}$ prostředí karbonátového vývoje jury, a tudíž spadají do druhé hydrogeochemické zóny.

\section{Metodika}

Za účelem upřesnění a objasnění původu, geneze a identifikace infiltračních oblastí a možného směru proudění vod byly vyhodnoceny nově realizované izotopové analýzy vodíku a kyslíku (stanovení $\delta^{2} \mathrm{H}$ a $\left.\delta^{18} \mathrm{O}\right)$ a zpracovány chemické analýzy termálních minerálních vod $\mathrm{z}$ jímacích objektů Muš-3G a Laa Th N1. Chemické analýzy k vrtu Muš-3G byly získány ze závěrečných zpráv (Adámek et al. 1990; Neudert 1995; Kocman 2020), zatímco k vrtu Laa Th N1 byly poskytnuty rakouskou geologickou službou (GBA - Geologische Bundesanstalt). Chemické analýzy k vrtu Pas-2G byly získány ze závěrečné zprávy (Neudert 1995). 
Tab. 1: Základní údaje o zdrojích termálních minerálních vod Muš-3G a Laa Th N1. Tab. 1: Basic data of thermal mineral water sources Muš-3G and Laa Th N1.

\begin{tabular}{|c|c|c|c|}
\hline Vrt & Souřadnice & Stratigrafie & Zdroj \\
\hline $\begin{array}{l}\text { Muš-3G } \\
(1455 \text { m) }\end{array}$ & $\begin{array}{l}\text { N } 48^{\circ} 54^{`} 17,8114^{\prime \prime} \\
\text { E } 16^{\circ} 34^{`} 35,0305^{\prime \prime} \\
\text { Z: } 184,11 \mathrm{~m} \mathrm{n} . \mathrm{m} .\end{array}$ & $\begin{array}{l}\text { 0-830 m: Karpat, eggenburg } \\
\text { 830-1 } 362 \mathrm{~m} \text { : Jura (malm), karbonátový } \\
\text { vývoj: altenmarktské souvrství } \\
\text { 1 362-1 } 435 \mathrm{~m} \text { : Jura (dogger - callovian), } \\
\text { bazální klastické souvrství: } \\
\quad \text { - } 1416 \mathrm{~m} \text { : nikolčické vrstvy } \\
\quad \text { - } 1435 \mathrm{~m} \text { : grestenské souvrství } \\
\text { 1435-1 } 455 \mathrm{~m} \text { : Krystalinikum - grani- } \\
\text { toidy } \\
1203,7-1 \text { 418,2 m: Perforace vrtu }\end{array}$ & Adámek et al. (1990) \\
\hline $\begin{array}{l}\text { Laa Th N1 } \\
(1448 \mathrm{~m})\end{array}$ & $\begin{array}{l}\text { N } 48^{\circ} 43^{`} 53,7421^{“} \\
\text { E } 16^{\circ} 23^{\prime} 22,2877^{\prime \prime} \\
\text { Z: } 183 \mathrm{~m} \mathrm{n.} \mathrm{m.}\end{array}$ & $\begin{array}{l}\text { 0-851,6 m: Karpat } \\
\text { 851,6-1 } 090 \mathrm{~m} \text { : Ottnang } \\
1 \text { 090-1 } 121 \mathrm{~m} \text { : Eggenburg } \\
1 \text { 121-1 } 125,3 \mathrm{~m} \text { : Eger } \\
1 \text { 125,3-1 } 448 \mathrm{~m} \text { : Jura (malm), karboná- } \\
\text { tový vývoj: altenmarktské souvrství } \\
1 \text { 122,5-1 } 448 \mathrm{~m} \text { : Perforace vrtu }\end{array}$ & Michalíček et al. (2005) \\
\hline
\end{tabular}

\section{Izotopy}

Nejdůležitější složky molekuly vody jsou stabilní izotopy ${ }^{16} \mathrm{O}$ a ${ }^{18} \mathrm{O}\left(\Rightarrow \delta^{18} \mathrm{O}\right)$ a ${ }^{1} \mathrm{H}$ a ${ }^{2} \mathrm{H}\left(\Rightarrow \delta^{2} \mathrm{H}\right)$, které mají nejširší pole působnosti ve studiích podzemních vod, například při zjištování jejich původu, způsobu doplňování nebo určování přibližného věku (Geyh 2000). Za účelem stanovení $\delta^{2} \mathrm{H}$ a $\delta^{18} \mathrm{O}$ ve zkoumaných vodách byl proveden odběr vzorků z hydrogeologických vrtů Muš-3G a Laa Th N1. Odběr vzorků vod z vrtu Muš-3G probíhal v týdenních intervalech se začátkem vzorkování dne 8. 11. 2018, přičemž celkově bylo odebráno 32 vzorků. Vzorkování vod z vrtu Laa Th N1 začalo 21. 8. 2019 a pokračovalo ve dvoutýdenních intervalech až do 16. 6. 2020, dohromady bylo odebráno 17 vzorků. Před samotnou izotopovou analýzou byla nutná destilace vzorků z důvodu vysoké mineralizace vod. Vzorky byly destilovány v chemické laboratoři Ústavu geologických věd PřF MUNI pomocí destilační kolony. Následně byly všechny vzorky odeslány do specializované laboratoře stabilních izotopů České geologické služby v Praze. Měření $\delta^{2} \mathrm{H}$ a $\delta^{18} \mathrm{O}$ ve vodách bylo provedeno pomocí laserové absorpční spektroskopie na př́stroji LWIA (Liquid Water Isotope Analyser 3000) od firmy LGR (Los Gatos Research, Inc.), jehož chyba měření dosahuje hodnot $\pm 0,7 \%$ pro $\delta^{2} \mathrm{H}$ a $\pm 0,2 \%$ pro $\delta^{18} \mathrm{O}$. Výsledné koncentrace izotopů se vztahují ke standardu V-SMOW a jsou uváděny v hodnotě delta $(\delta)$, která vyjadřuje poměr nejvzácnějších $\mathrm{k}$ nejběžnějším (resp. těžkých ku lehkým) izotopům v analyzovaném vzorku (Geyh 2000). V př́rodních meteorických vodách platí lineární vztah mezi $\delta^{2} \mathrm{H}$ a $\delta^{18} \mathrm{O}$ známý jako světová linie meteorických vod GMWL (Global Meteoric Water Line), který lze vyjádřit rovnicí 1 (Craig 1961):

$$
\delta^{2} \mathrm{H}=8 \delta^{18} \mathrm{O}+10 \%
$$

Pro každou oblast je možné určit i lokální linii meteorických vod LMWL, kterou je třeba stanovit na základě vzorkování místních srážek včetně sněhu (Clark, Fritz 1997). Z hlediska lokalizace studované oblasti je v grafické interpretaci výsledků izotopových analýz vynesena kromě světové i lokální vídeňská linie meteorických vod (Vienna MWL), která vychází ze vztahu uvedeného $\mathrm{v}$ rovnici 2 (Hager, Foelsche 2015):

$$
\delta^{2} H=7,5 \delta^{18} \mathrm{O}+3,2 \% o
$$

Podzemní voda v konkrétní oblasti má obvykle hodnoty $\delta^{2} \mathrm{H}$ a $\delta^{18} \mathrm{O}$ odpovídající váženému průměru srážek (Clark, Fritz 1997). Z toho důvodu je pro lepší interpretaci a korelaci výsledného izotopového složení zkoumaných vod do grafu vynesen rovněž bod VIENNA reprezentující průměrné izotopové složení recentních srážek ve studovaném regionu, konkrétně pro měrnou stanici Vienna (AT) - jedná se o bod sítě IAEA (International Atomic Energy Agency) zapojené do programu GNIP (International Atomic Energy Agency 2021).

\section{Chemismus a mineralizace vod}

K vyhodnocení chemických analýz termálních minerálních vod z vrtů Muš-3G a Laa Th N1 byl využit tabulkový editor GSS programu Geochemist's Workbench, který umožňuje grafické znázornění chemického složení jednotlivých vzorků vod. Celkově bylo zpracováno 27 chemických analýz, z toho 20 z vrtu Muš-3G a 7 analýz z vrtu Laa Th N1. Pro lepší interpretaci a korelaci vod bylo zpracováno dalších 8 chemických analýz z reinjektážního vrtu Pas-2G. Všechny analýzy vod pocházejí z prostředí jurských sedimentů.

Se záměrem určení hydrochemického typu vod a zobrazení rozdílů $\mathrm{v}$ chemickém složení a celkové mineralizaci vod z obou oblastí byl využit Durovův klasifikační diagram (Durov 1948) a ternární diagram. V Durovově diagramu jsou vyneseny relativní koncentrace hlavních kationtů $\left(\mathrm{Ca}^{2+}, \mathrm{Mg}^{2+}, \mathrm{Na}^{+}+\mathrm{K}^{+}\right)$a aniontů $\left(\mathrm{SO}_{4}{ }^{2-}, \mathrm{Cl}^{-}\right.$, $\left.\mathrm{HCO}_{3}{ }^{-}+\mathrm{CO}_{3}{ }^{2-}\right)$, přičemž je rozšíren o čtverec umožňující interpretování analýz z hlediska celkového množství rozpuštěných látek ve vodě (TDS/celková mineralizace). Dále byl využit ternární diagram s vynesenými relativními koncentracemi iontů $\mathrm{Cl}^{-}, \mathrm{HCO}_{3}^{-}$a $\mathrm{Na}^{+}$, které nejlépe charakterizují rozdíly mezi zkoumanými vodami.

$\mathrm{V}$ přírodních systémech běžně dochází $\mathrm{k}$ mísení vod, které vede ke změně jejich kvalitativních vlastností. Nejčastěji se setkáváme s vodami, které vznikly ze dvou nebo i více typů vod. Aby bylo možné určit množství (objem) původních vod, je třeba znát jejich chemické složení nebo alespoň koncentraci jedné složky. Mísení dvou typů vod je možné popsat směšovací rovnicí (3):

$C_{m} V_{m}=C_{1} V_{1}+C_{2} V_{2}$

kde $m, 1$ a 2 označují koncentrace (C) a objemy (V) směsi $m$ a jednotlivých roztoků 1 a 2 . Při každé determinaci mísení vod je vhodné udělat alespoň dva výpočty, tj. do rovnice dosadit alespoň dvě nereaktivní složky, např. bromidy $\left(\mathrm{Br}^{-}\right)$a chloridy $\left(\mathrm{Cl}^{-}\right)$, a následně porovnat jejich výsledky, které by měly být přibližně stejné (Langmuir 1997). Využití směšovací rovnice v této studii je založeno na předpokladu, že výsledná voda ve vrtech 


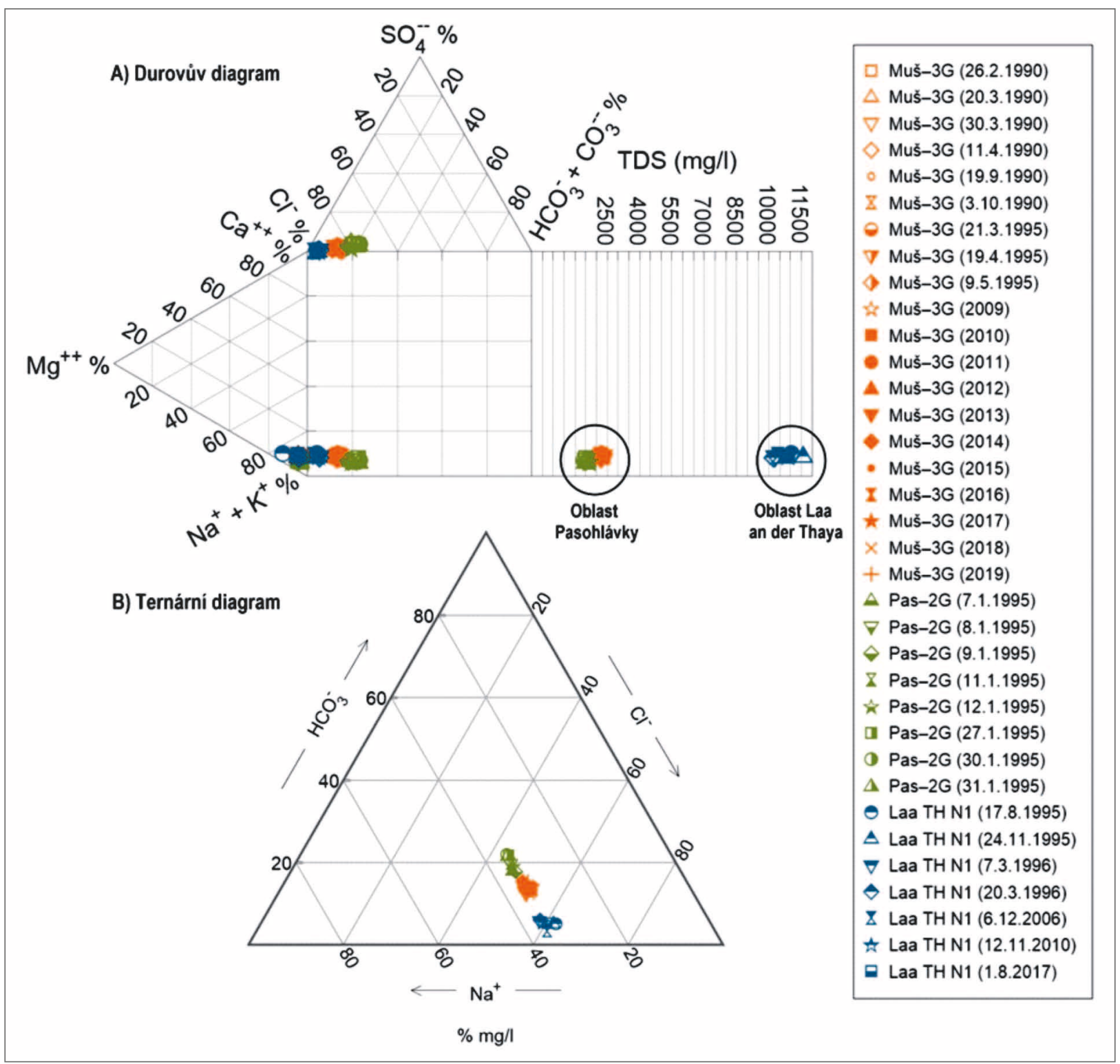

Obr. 2: Durovův a ternární diagram s vynesenými chemickými analýzami termálních minerálních vod z vrtů Muš-3G, Laa Th N1 a Pas-2G.

Fig. 2: Durov and ternary diagram with plotted chemical analyses of thermal mineral waters from wells Muš-3G, Laa Th N1 and Pas-2G.

je směs primární mořské vody a infiltrované meteorické vody. Pomocí upraveného tvaru směšovací rovnice (3) byl vypočten přibližný obsah primární mořské vody v obou zkoumaných vrtech, a to na základě koncentrací $\mathrm{Cl}^{-}$a $\mathrm{Br}^{-}$, kde:

$\mathrm{C}_{\mathrm{m}}$ - průměrná koncentrace $\mathrm{Cl}^{-}$nebo $\mathrm{Br}^{-}$ve vodách $\mathrm{z}$ vrtů $\mathrm{v} \mathrm{mg} / \mathrm{L}$,

$\mathrm{C}_{1}$ - koncentrace $\mathrm{Cl}^{-}$nebo $\mathrm{Br}^{-} \mathrm{v}$ průměrné povrchové vodě (Livingstone 1963) reprezentující koncentrace pro infiltrovanou meteorickou vodu:

- $\mathrm{Cl}^{-}=7,8 \mathrm{mg} / \mathrm{L}$,

- $\mathrm{Br}^{-}=$zanedbatelné množství, do výpočtu zadána hodnota $0,01 \mathrm{mg} / \mathrm{L}$,

$\mathrm{C}_{2}$ - koncentrace $\mathrm{Cl}^{-}$nebo $\mathrm{Br}^{-} \mathrm{v}$ průměrné mořské vodě (Horn 1969) reprezentující koncentrace v primární mořské vodě, za předpokladu stálého chemického složení mořské vody v průběhu geologických období:

- $\mathrm{Cl}^{-}=19000 \mathrm{mg} / \mathrm{L}$,

- $\mathrm{Br}^{-}=65 \mathrm{mg} / \mathrm{L}$,

$\mathrm{V}_{\mathrm{m}}$ - představuje 1 litr resp. $100 \%$,

$\mathrm{V}_{1}$ a $\mathrm{V}_{2}$ - vypočtené obsahy infiltrované meteorické a primární mořské vody v aktuálně čerpaných vodách $\mathrm{z}$ vrtů Muš-3G a Laa Th N1.

Na základě vypočtených přibližných obsahů primární mořské vody $\left(\mathrm{V}_{2}\right)$ a infiltrované meteorické vody $\left(\mathrm{V}_{1}\right)$ ve vrtech a známého izotopového složení $\delta^{2} \mathrm{H}$ a $\delta^{18} \mathrm{O}$ jednak vody ve vrtech $\left(\mathrm{C}_{\mathrm{m}}\right)$ a jednak primární mořské vody $\left(\mathrm{C}_{2}\right)$, protože představuje standard V-SMOW, bylo možné dopočítat přibližné izotopové složení infiltrované meteorické vody $\left(\mathrm{C}_{1}\right)$ přitékající do prostředí jurských sedimentů v okolí vrtu Muš-3G. Za jednotlivé členy rovnice se zvlášt dosadily hodnoty na výpočet $\delta^{2} \mathrm{H}$ a zvlášt’ 
Tab. 2: Průměrné koncentrace hlavních kationtů a aniontů ve vodách $\mathrm{z}$ vrtů Laa Th N1, Muš-3G a Pas-2G.

Tab. 2: Mean concentrations of major cations and anions in waters from wells Laa Th N1, Muš-3G and Pas-2G.

\begin{tabular}{|l|c|c|c|c|c|c|}
\hline \multirow{2}{*}{ Vrt } & $\mathbf{N a}^{+}+\mathbf{K}^{+}$ & $\mathbf{C a}^{2+}$ & $\mathbf{M g}^{2+}$ & $\mathbf{C l}^{-}$ & $\mathbf{S O}_{4}{ }^{2-}$ & $\mathbf{H C O}_{3}^{-}$ \\
\cline { 2 - 7 } & {$[\mathrm{mg} / \mathrm{L}]$} & {$[\mathrm{mg} / \mathrm{L}]$} & {$[\mathrm{mg} / \mathrm{L}]$} & {$[\mathrm{mg} / \mathrm{L}]$} & {$[\mathrm{mg} / \mathrm{L}]$} & {$[\mathrm{mg} / \mathrm{L}]$} \\
\hline Laa Th N1 & 3564,43 & 204,19 & 125,31 & 6222,29 & 5,88 & 520,7 \\
\hline Muš-3G & 721,73 & 44,07 & 18,9 & 1097,76 & 25,84 & 286,58 \\
\hline Pas-2G & 501,53 & 22,59 & 10,94 & 653,64 & 34,24 & 284,18 \\
\hline
\end{tabular}

Tab. 3: Vstupní údaje pro směšovací rovnici na stanovení přibližného obsahu infiltrované meteorické a primární mořské vody v kolektoru jurských hornin $\mathrm{v}$ obou oblastech $\left(\mathrm{V}_{1}\right.$ a $\mathrm{V}_{2}$ hodnoty vyznačené kurzívou).

Tab. 3: Input data for the mixing equation to determine the approximate content of infiltrated meteoric water and primary seawater in the Jurassic aquifer in both areas $\left(\mathrm{V}_{1}\right.$ and $\mathrm{V}_{2}-$ values marked in italics).

\begin{tabular}{|l|c|c|c|c|c|c|c|}
\hline \multirow{2}{*}{ Vrt } & \multirow{2}{*}{ ion } & $\begin{array}{c}\text { inf. meteor. } \\
\text { voda }\end{array}$ & $\begin{array}{c}\text { mořská } \\
\text { voda }\end{array}$ & voda z vrtu & $\begin{array}{c}\text { inf. meteor. } \\
\text { voda }\end{array}$ & $\begin{array}{c}\text { mořská } \\
\text { voda }\end{array}$ & voda z vrtu \\
\cline { 3 - 8 } & & $\mathrm{C}_{1}[\mathrm{mg} / \mathrm{L}]$ & $\mathrm{C}_{2}[\mathrm{mg} / \mathrm{L}]$ & $\mathrm{C}_{\mathrm{m}}[\mathrm{mg} / \mathrm{L}]$ & $\mathrm{V}_{1}[\mathrm{~L}]$ & $\mathrm{V}_{2}[\mathrm{~L}]$ & $\mathrm{V}_{\mathrm{m}}[\mathrm{L}]$ \\
\hline \multirow{2}{*}{ Muš-3G } & $\left(\mathrm{Cl}^{-}\right)$ & 7,8 & 19000 & 1097,76 & 0,94 & 0,06 & 1 \\
\cline { 2 - 8 } & $\left(\mathrm{Br}^{-}\right)$ & 0,01 & 65 & 4,63 & 0,93 & 0,07 & 1 \\
\hline \multirow{2}{*}{ Laa Th N1 } & $\left(\mathrm{Cl}^{-}\right)$ & 7,8 & 19000 & 6222,29 & 0,67 & 0,33 & 1 \\
\cline { 2 - 8 } & $\left(\mathrm{Br}^{-}\right)$ & 0,01 & 65 & 27,6 & 0,58 & 0,42 & 1 \\
\hline
\end{tabular}

na výpočet $\delta^{18} \mathrm{O}$. Za $\mathrm{V}_{1}$ a $\mathrm{V}_{2}$ byly do výpočtu použity hodnoty odvozené $\mathrm{z}$ koncentrace chloridů.

\section{Výsledky a diskuze \\ Chemismus a mineralizace vod}

K hydrochemickému zhodnocení termálních minerálních vod byl využit Durovův klasifikační diagram s vynesenými chemickými analýzami vod z vrtů Muš-3G, Laa Th N1 a Pas-2G (obr. 2A). Průměrné koncentrace hlavních kationtů a aniontů ve zkoumaných vodách jsou uvedeny v tabulce 2. Minerální vody v oblasti Pasohlávek (vrt Muš-3G a Pas-2G) jsou chlorido-sodného (Na-Cl) typu $s$ celkovou mineralizací 2,2 g/L u vrtu Muš-3G, respektive 1,6 g/L u vrtu Pas-2G. Z minoritních složek obsahují značné koncentrace bromidů $\mathrm{Br}^{-}(1,9-8,9 \mathrm{mg} / \mathrm{L})$ a jodidů $\mathrm{I}^{-}$(0,1-2,3 mg/L), které jsou důležité z hlediska posouzení geneze vod. Z rozpuštěných plynů ve vodě převládá metan $\mathrm{CH}_{4}$ (63,7-83,6 obj. \%), druhou nejvýznamnější složkou je dusík $\mathrm{N}_{2}$ (15,0-31,5 obj. \%). Typická je i př́tomnost rozpuštěného sirovodíku $\mathrm{H}_{2} \mathrm{~S}(4,2-8,9 \mathrm{mg} / \mathrm{L})$, který vodám dodává charakteristický zápach. Minerální vody z oblasti Laa (vrt Laa Th N1) jsou taktéž Na-Cl typu, avšak celková mineralizace dosahuje hodnot $11 \mathrm{~g} / \mathrm{L}$. Zvýšené jsou i obsahy bromidů $(23,5-31,6 \mathrm{mg} / \mathrm{L})$ a jodidů $(8,9-9,5 \mathrm{mg} / \mathrm{L})$. Dominantní složkou rozpuštěných plynů ve vodě je metan $\mathrm{CH}_{4}\left(88,1-94,4\right.$ obj. \%), následovaný dusíkem $\mathrm{N}_{2}$ (2,8-9,5 obj. \%), přičemž voda $\mathrm{v}$ Laa neobsahuje žádný sirovodík $\mathrm{H}_{2} \mathrm{~S}$. Podle Adámka et al. (1990) pochází metan ve zkoumaných vodách pravděpodobně z hlouběji ponořených částí mezozoika, kde se tvoří jako přirozený produkt procesu degradace organické hmoty. Rovněž předpokládá, že dusík je převážně atmogenního původu, zatímco původ rozpuštěného sirovodíku ve vodách v oblasti Pasohlávek je pravděpodobně spojen s bakteriální redukcí síranů při rozkladu organické hmoty (Adámek et al. 1990).
Z důvodu jednotného hydrochemického typu vod Na-Cl v jurské zvodni obou oblastí je důležitým diferenčním parametrem celková mineralizace vod, která je $\mathrm{v}$ Laa přibližně $5 \times$ vyšší než v oblasti Pasohlávek (obr. 2A). Pomocí směšovací rovnice byla stanovena přibližná množství infiltrované meteorické a primární mořské vody v kolektoru jurských hornin v obou oblastech. Voda v Laa obsahuje cca 33 až $42 \%$ primární mořské vody, zatímco voda v Pasohlávkách pouze cca 6 až $7 \%$ (tab. 3).

Z hlediska zastoupení hlavních iontů představuje podstatný rozdíl mezi vodami relativní koncentrace hydrogenuhličitanů $\left(\mathrm{HCO}_{3}{ }^{-}\right)$, jak je zjevné z ternárního diagramu (obr. $2 \mathrm{~B}$ ). Nejvyšší relativní koncentrace $\mathrm{HCO}_{3}{ }^{-}$mají méně mineralizované vody z vrtu Pas-2G situovaného $2,6 \mathrm{~km} \mathrm{z}$. od vrtu Muš-3G, naopak nejnižší relativní koncentrace $\mathrm{HCO}_{3}^{-}$ jsou ve výše mineralizovaných vodách $z$ vrtu Laa Th N1. Z diagramů rovněž vyplývá, že i při dlouhodobém jímání vod $\mathrm{z}$ vrtu Muš-3G nedochází $\mathrm{k}$ výrazné změně chemismu ani celkové mineralizace vod, jak dokládá poměrně neměnné složení chemických analýz z let 2009-2019 (k intenzivnímu čerpání vod dochází od roku 2013).

Důležitými ukazateli marinogenního původu vod jsou, spolu s výrazným Na-Cl typem vod, i zvýšené obsahy bromidů a jodidů. Naopak přítok meteorických vod z infiltračních oblastí dokládají zvýšené koncentrace $\mathrm{HCO}_{3}^{-}$, přítomnost atmogenního dusíku vázaného na meteorické vody a pokles celkové mineralizace vod. Původně marinogenní vody v jurském kolektoru jsou výrazně ovlivňovány a degradovány meteorickými vodami z infiltračních oblastí. Vody z prostředí jurských sedimentů v oblasti Pasohlávek vykazují výrazně vyšší infiltrační degradaci původních marinogenních vod ve srovnání s vodami z Laa. Vyšší intenzita infiltrační degradace je charakteristická pro okraje hydrogeologických struktur situovaných blíže $\mathrm{k}$ infiltračním územím, zatímco směrem k centrálním částem struktur dochází k jejímu snižování. Infiltrační degradace je tak jedním z faktorů dokládajících otevřenost, resp. polootevřenost hydrogeologické struktury (Franko et al. 1975). Rozdíly v chemickém složení a odlišná intenzita mísení vod v obou oblastech mohou být zčásti způsobeny i geologickou stavbou a hlubinnými tektonickými poruchami horninového prostředí. 


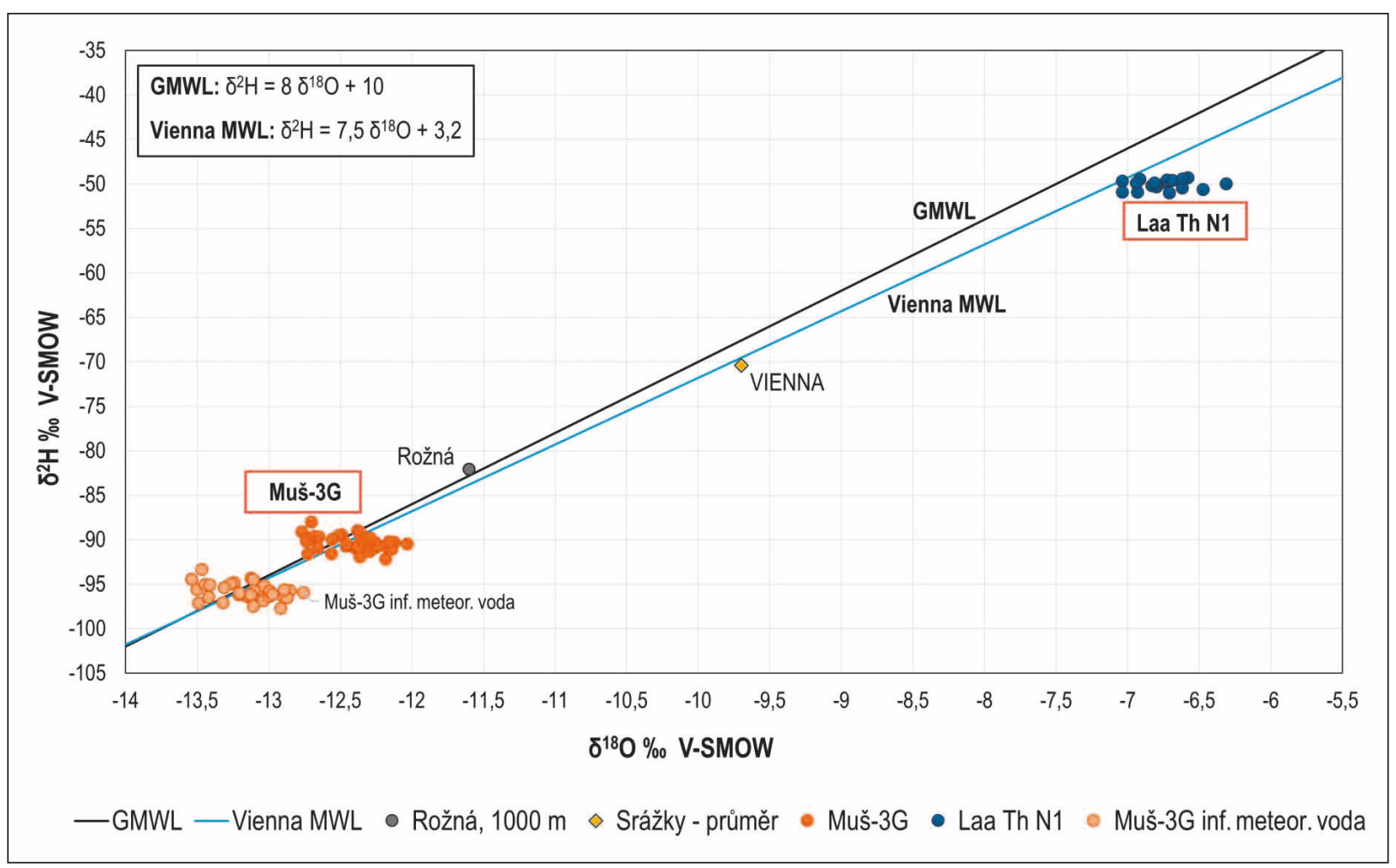

Obr. 3: Porovnání izotopového složení termálních vod z vrtů Muš-3G a Laa Th N1 s vodami z dolu Rožná z hloubky $1000 \mathrm{~m}$ (Dvořáková et al. 2014). Bod VIENNA reprezentuje průměrné izotopické složení recentních srážek v studovaném regionu.

Fig. 3: Comparison of the isotopic composition of thermal waters from wells Muš-3G and Laa Th N1 with waters from the Rožná mine from a depth of $1000 \mathrm{~m}$ (Dvořáková et al. 2014). The VIENNA point represents the average isotopic composition of recent precipitation in the studied region.

\section{Izotopy}

Výsledné hodnoty izotopů $\delta^{2} \mathrm{H}$ a $\delta^{18} \mathrm{O}$ jsou vyneseny do grafu se světovou a vídeňskou linií meteorických vod (obr. 3). Izotopové složení vody z vrtu Muš-3G se pohybuje v hodnotách od $-12,77 \%$ o do $-12,03 \%$ pro $\delta^{18} \mathrm{O}$ a od $-92,23 \%$ do $-88,05 \%$ o pro $\delta^{2} \mathrm{H}$, zatím co vody $\mathrm{z}$ vrtu Laa Th N1 jsou výrazně izotopicky těžší s hodnotami $\delta^{18} \mathrm{O}$ pohybujícími se od $-7,04 \%$ o do $-6,31 \%$ a hodnotami $\delta^{2} \mathrm{H}$ od $-51,04 \%$ do $-49,33 \%$. Mírná variabilita v hodnotách $\delta^{18} \mathrm{O}$, projevující se odchýlením od GMWL (obr. 3), je způsobena nepřesností laboratorního měření.

Na základě vypočteného přibližného obsahu primární mořské vody $\mathrm{v}$ kolektoru jurských hornin v Pasohlávkách (cca 6\%) a známého izotopového složení vod bylo možné, pomocí směšovací rovnice (rovnice 3), stanovit izotopové složení meteorických vod přitékajících do prostředí jury v okolí vrtu Muš-3G (tab. 4, obr. 3).

Rozdíl v obsahu primární mořské vody má velký vliv na výsledné izotopové složení vod v obou regionech. $S$ rostoucím obsahem mořských vod se stávají vody izotopicky těžšími, protože mořská voda je standardem pro izotopy vodíku a kyslíku, a tedy nabývá hodnot $0 \%$. $\mathrm{Z}$ hlediska zastoupení stabilních izotopů $\delta^{2} \mathrm{H}$ a $\delta^{18} \mathrm{O}$ jsou termální minerální vody $\mathrm{z}$ jurských sedimentů v oblasti Laa výrazně izotopicky těžší v porovnání s vodami v oblasti Pasohlávek a zároveň jsou těžší i ve srovnání s průměrným izotopovým složením recentních srážek ve studovaném regionu (bod VIENNA), a to právě z důvodu vyššího obsahu primární mořské vody (cca $38 \%$ ). Naopak vody z jurských sedimentů v oblasti Pasohlávek jsou výrazně izotopicky ochuzeny oproti recentním srážkám i vodám z oblasti Laa, což naznačuje přítomnost vyššího podílu meteorické vody infiltrované při nižších průměrných ročních teplotách než v současnosti, která je izotopicky velmi lehká. Výsledky tak naznačují, že vody přitékající do jury v oblasti Pasohlávek infiltrovaly v chladném klimatickém období - glaciálu. Obdobné izotopové složení vykazují podzemní vody odebrané $\mathrm{v}$ dole Rožná $\mathrm{z}$ hloubky $1 \mathrm{~km}$, jejichž věk byl určen datováním radiouhlíkovou metodou $\left({ }^{14} \mathrm{C}\right)$ na 17 až 22 tisíc let - do období posledního glaciálu (Dvořáková et al. 2014). Infiltrovaná voda v juře v okolí Pasohlávek tak může být

Tab. 4: Vstupní údaje pro směšovací rovnici na výpočet přibližného izotopového složení infiltrované meteorické vody ve vrtu Muš-3G ( $\mathrm{C}_{1}$ - hodnoty vyznačené kurzívou).

Tab. 4: Input data of the mixing equation for calculation of the approximate isotope composition of infiltrated meteoric water in the Muš-3G well ( $\mathrm{C}_{1}$ - values marked in italics).

\begin{tabular}{|l|c|c|c|c|c|c|}
\hline \multirow{2}{*}{$\begin{array}{l}\text { Stabilní } \\
\text { izotop }\end{array}$} & $\begin{array}{c}\text { inf. meteor. } \\
\text { voda }\end{array}$ & $\begin{array}{c}\text { mořská } \\
\text { voda }\end{array}$ & $\begin{array}{c}\text { voda } \\
\mathbf{z} \text { Muš-3G }\end{array}$ & $\begin{array}{c}\text { inf. meteor. } \\
\text { voda }\end{array}$ & $\begin{array}{c}\text { mořská } \\
\text { voda }\end{array}$ & $\begin{array}{c}\text { voda } \\
\text { z Muš-3G }\end{array}$ \\
\cline { 2 - 7 } & $\mathrm{C}_{1}[\%]$ & $\mathrm{C}_{2}[\% 0]$ & $\mathrm{C}_{\mathrm{m}}[\% 0]$ & $\mathrm{V}_{1}[\mathrm{~L}]$ & $\mathrm{V}_{2}[\mathrm{~L}]$ & $\mathrm{V}_{\mathrm{m}}[\mathrm{L}]$ \\
\hline $\boldsymbol{\delta}^{2} \mathbf{H}$ & $-95,88$ & 0 & $-90,44$ & 0,94 & 0,06 & 1 \\
\hline $\boldsymbol{\delta}^{\mathbf{1 8}} \mathbf{O}$ & $-13,15$ & 0 & $-12,41$ & 0,94 & 0,06 & 1 \\
\hline
\end{tabular}


přibližně stejně stará nebo i starší, protože je izotopicky více ochuzena.

\section{Závěr}

Předložená studie se zabývá hydrochemickým zhodnocením zdrojů termálních minerálních vod v oblasti Pasohlávky a Laa. Termální minerální vody jsou vázány na hluboko položené těleso jurských sedimentů, přičemž jsou jímány prostřednictvím vrtů Muš-3G a Laa Th N1. Chemickými analýzami byl identifikován dominantní typ vod $\mathrm{Na}-\mathrm{Cl}$ v prostoru obou hodnocených vrtů. Vody v okolí vrtu Muš-3G se, ve srovnání s vodami na rakouské straně, vyznačují nižší mineralizací, která je spojena $\mathrm{s}$ vyššími koncentracemi $\mathrm{HCO}_{3}{ }^{-}$a atmogenního dusíku, typicky vázaného na infiltrované meteorické vody. Dle výsledků nejnovějších analýz stabilních izotopů vodíku a kyslíku, realizovaných v letech 2018-2020, odpovídá nižší celková mineralizace izotopicky lehčím vodám infiltrovaným pravděpodobně $\mathrm{v}$ chladném klimatickém období (glaciálu). Termální vody v Pasohlávkách jsou tak $\mathrm{v}$ současnosti $\mathrm{z}$ velké části tvořeny infiltrovanými meteorickými vodami smíšenými s primární vodou marinogenní. Naopak vyšší podíl primární mořské vody v Laa dokládá vyšší celková mineralizace, zvýšené koncentrace bromidů a jodidů a nižší koncentrace $\mathrm{HCO}_{3}^{-}$. Na celkovém chemickém složení zkoumaných vod se významně podílí proces mísení primárních mořských vod s infiltrovanými meteorickými vodami, přičemž původní marinogenní typ vod $\mathrm{Na}-\mathrm{Cl}$ zůstává zachován. Rozdíly v chemickém složení a odlišná intenzita mísení vod v obou oblastech jsou, mimo jiné, způsobeny také geologickou stavbou a hlubinnými tektonickými poruchami horninového prostředí.

Tato studie se opírá, vychází a navazuje na poznatky $\mathrm{z}$ archivních dokumentací a závěrečných prací a zároveň doplňuje nová zjištění o zdrojích termálních minerálních vod Muš-3G v Pasohlávkách a Laa Th N1 v Laa an der Thaya.

\section{Poděkování}

Tato studie vznikla $v$ rámci přeshraničního projektu Interreg HTPO (Hydrotermální potenciál oblasti, ATCZ167). Poděkování patři editorovi a recenzentưm za cenné komentáre a podnětné připomínky, které vedly ke zkvalitnění príspěvku.

\section{Literatura}

Adámek, J. (1974). Hluboký strukturní průzkum oblasti Mušov, etapa II. - MND. Hodonín.

Adámek, J. (1986). Geologické poznatky o stavbě mezozoika v úseku jih jihovýchodních svahů Českého masivu. - Zemní plyn a nafta, 31, 4, 453-484.

Adámek, J. (2005). The Jurassic floor of the Bohemian Massif in Moravia - geology and paleogeography. - Bulletin of Geosciences, 80, 4, 291-305. Pilsen.

Adámek, J., Balun, P., Dostálek, J., Guryča, I., Jandová, B., Karbanová, E., Michalíček, M., Němcová, A., Řehánek, J. (1990). Vyhledávací průzkum zdroje vody Mušov 3-G - Závěrečná zpráva o geotermálním vrtu MUŠOV - $3(\mathrm{G})$. - Moravské naftové doly, s.p. odbor průzkumné geologie. Hodonín.

Adámek, J., Guryča, I., Řehánek, J., Holinka, K., Kotásek, V., Husák, P., Karbanová, E. (1995). Závěrečná geologická zpráva o reinjektážním vrtu Pasohlávky-2G. - Moravské naftové doly, a.s. odbor průzkumné geologie. Hodonín.

Clark, I., Fritz, P. (1997). Environmental Isotopes in Hydrogeology. - CRC Press/Taylor \& Francis Group. Boca Raton.

Craig, H. (1961). Isotopic Variations in Meteoric Waters. - Science, 133, 1702-1703. https://doi.org/10.1126/science.133.3465.1702

Durov, S. A. (1948). Natural Waters and Graphic Representation of Their Composition. - Doklady Akademii Nauk SSSR, 59, 87-90.

Dvořáková, M., Vencl, M., Kř́ǐz, P. (2014). Budování podzemního výzkumného pracoviště Bukov. - Tunel, 23, 2, 18-22.

Eliáš, M. (1974). Mikrofaciální výzkum karbonátů naftonadějných oblastí na př́kladě autochtonní jury jihovýchodních svahů českého masivu. - Zemní plyn a nafta, 19, 3, 359-374.

Franko, O., Gazda, S., Michalíček, M. (1975). Tvorba a klasifikácia minerálnych vôd Západných Karpát. - Geologický ústav Dionýza Štúra. Bratislava.

Geyh M. (2000). Groundwater. Saturated and unsaturated zone. - In: Mook, W.G. (ed.): Environmental Isotopes in the Hydrological Cycle. Principles and Applications. Technical document in hydrology, n.39, vol. IV, 196 p. UNESCO, Paris.

Hager, B., Foelsche, U. (2015). Stable isotope composition of precipitation in Austria. - Austrian Journal of Earth Sciences, 108, 2, 2-13.. Vienna. https://doi.org/10.17738/ajes.2015.0012

Horn, R. A. (1969). Marine Chemistry. - Wiley. New York.

International Atomic Energy Agency (2021). Global Network of Isotopes in Precipitation (GNIP). - Dostupné na: http://www-naweb.iaea.org/napc/ih/IHS_resources_gnip.html, 05.10.2021

Kocman, T. (2020). Expertní vyhodnocení režimních měření na vrtu MU3G. - KOCMAN envimonitoring. Brno.

Langmuir, D. (1997). Aqueous environmental geochemistry. - Upper Saddle River, N.J. Prentice Hall.

Livingstone, D. A. (1963). Chemical composition of rivers and lakes, 6th edition. - U.S. Geological Survey Professional Paper $440-\mathrm{G}, 64 \mathrm{~s}$.

Michalíček, M., Petrová, V., Repková, H. (2005). Studie termální a minerální vody jižní a střední Moravy. - Česká geologická služba. Brno.

Neudert, O. (1995). Dílčí závěrečná zpráva o reinjektážním vrtu Pasohlávky-2G - Soubor výsledků analýz vod a plynů. - GIAS, Geologické inženýrství a.s. Brno. 